\title{
WALT WHITMAN LAUGHS: AN UNCOLLECTED PIECE OF PROSE JOURNALISM
}

\author{
Martin G. Murray
}

Humor, POLITICs, AND ART are the subjects of an uncollected piece of Walt Whitman's journalism published on October 17, 1872, in the Washington Evening Star. Portraying the poet laughing "enormously" at some comic sketches by the Republican political satirist Thomas Nast, the article lauds the development of the editorial cartoon as an American art form. The unsigned contribution appeared on page 1 in the regular column entitled "Washington News and Gossip":

IT HAS BEEN GOOD FUN to-day observing the groups gathered around Shillington's, Beal's, Parker's, Robert Reill's, Bishop's, and the other periodical stores of the Avenue and $7^{\text {th }}$ street, to look at Nast's latest comic pictures, "The Tidal Wave" and the irresistible "Do you see anything green in my eye?" Both are strokes of genius, and, judging by Washington city, the appreciation of this sort of thing is complete. The motley crowds, by dozens and scores, big and little, old and young, white, black and brown, learned and illiterate, all made it plain enough "where the laugh came in." In fact it was one general smile varied by guffaws, grins, and every known form of cachinnation. Here was a stray Senator or Representative, there a head of a bureau or even Department, swarms of clerks up to 9 o'clock, visitors, the colored people, the "knights," mechanics - the whole mass put in merry humor by these amusing cartoons. Among the rest of the jolly heads in one group on the Avenue, we saw the white locks and red face of Walt Whitman, proving that he can, on due provocation, laugh enormously, (notwithstanding some of his foreign critics,) and was now doing the same.

The general pictorial illustration business, and especially the original comic line, is certainly going to develop-or is already developed-into a great American institution. Already we compete with the best English and German wood-engravings, and their artists and designs; the French only are ahead of us. But we shall yet, and soon, outstrip the whole world. We have more of the spirit of fun in us, as a people, than any other. It is racy, a perennial product of the soil, the breed. Nast is the Moses who has smitten the rock, and the waters are already beginning to gush forth. Several of the inferior comic papers also show talent of the first order in every number. Then there is something in the pictorial art that affords a subtler, juicier, more appropriate medium for the expression of absolute humor than any other artistic outlet.

From all and several of which we launch the prophecy that Art in America is going to loom up in at least one new and special institution of the first class, the Pictorial 
Comic. For there is unquestionably the droll side of life, and all its affairs, persons, politics, everything - and even as an influence of civilization-such chaps as Nast, and others whose names we would give, if we knew them-show that "in the hands of men entirely great," the burin too is mightier than the sword.

Whitman's authorship is confirmed by an extant manuscript in Yale's Beinecke Library, which is nearly identical to the published piece. ${ }^{1}$ In particular, the manuscript reads as follows:

\section{Seores of}

read proof

carefully \& copy

verbatim and punctuation

It has been good fun to-day seing watehing

observing the groups gathered around Shillingtons,

Beal's, Parker's, Robert Reill's, Bishop's, and the

other periodical stores of the Avenue and

Seventh street, to look at Nasts latest comic

pictures, "the Tidal Wave" and the irresist-

ible "Do you see any thing green in my

eye?" Both are strokes of genius, and judging by Washington city, their the appreciation of this sort of thing is complete.

The

motley crowds, by dozens and scores, big and little, old and young,

white, black and brown, learned and illiterate,

all made it plain enough exhibited "where the laugh came in-." by In fact it was

one general eontinual smile varied by guffaws,

grins grins, and every known all forms of cachinnation.

Here was A stray Senator or Representative, there a

head of a Bureau or even Department, swarms

of clerks up to nine o'clock, visitors, the colored people, the

"knights," mechanics-the whole mass --all put in a merry

humor by these amusing cartoons. Among

[sheet 2]

the erowd we saw Walt Whitman

fatenjoying the pietures \& the seene, his

with-us with about as mueh

the rest we saw W

the rest of the jolly heads, in one of these the-groups on the Avenue, we saw

the white locks and red face of Walt

Whitman, who proving that he eutt can, on due provocation, ean laugh enormously,

(notwithstanding some of his foreign critics,) and

was now doing his best. the same.

21 As The general ${ }^{\text {pictorial }}$ illustration 
business, and especially in the original comic pieture-line, is certainly devet going to develope - or is already developedinto a great American institution. Already we outst compete with the best English and German wood-engravings, and their artists \& designs; the French only are ahead of us. But we shall yet, and soon, outstrip

[sheet 3]

burin

the whole world. We have more of the spirit of fun

in us, as a people, than any other.

It is racy, a ${ }^{\text {perennial }}$ genuine product of

the soil, the breed. Nast is the

Moses who has smote ${ }^{\text {smitten }}$ the rock and

the reatwaters are already beginning to gush forth. Several of the inferior comic papers also show talent of the first order in every number. Then Tthere is something in the pictorial art that affords a subtler, jucier, more appropriate medium for the expression of absolute humor funthan any other artistic outlet form. If From all \& several of which we launch forth out the prophecy that Art in America it going to loom up in a ${ }^{\text {at least one }}$ new and special institution of the first class, the Pictorial Comic. For there is eertainly unquestionably that the droll side of life, \& all its affairs, persons, politics and every thing - and [illeg. even as an influence of civilization- such chaps as Nast, (and others that might whose names we would give, if [illeg] we knew them-show that "in the hands of men entirely great," the burin too is mightier than the sword.

Whitman's piquant prose opens a window onto the poet's personal and world view during what would be his final year of residence in the nation's capital. Having arrived in the winter of 1862-1863 at the height of the Civil War, Whitman remained in Washington, DC, initially as a volunteer visitor to the war's casualties and later as an Executive Branch employee (primarily in the Office of the Attorney General of the United States) under Presidents Abraham Lincoln, Andrew Johnson, and Ulysses S. Grant. Whitman published two new editions of Leaves of Grass (1867 and 1871-72) and a major prose work, Democratic Vistas (1871), during this period. His social life revolved around his friendships with Peter Doyle, a horsecar conductor who may have been his lover; 
Charley Eldridge, his former publisher (1860 Leaves of Grass) and a Treasury Department attorney; naturalist John Burroughs and his wife Ursula; and writer and Federal clerk William O'Connor and his wife Ellen, abolitionists and advocates for the rights of freedmen and champions of Whitman's poems. He was both participant in and observer of Washington's street life that centered on the commercial corridor of Pennsylvania Avenue and Seventh Street, NW. He could be found posing for his photograph at the nearby studios of Mathew Brady and Alexander Gardner, attending musical and dramatic performances at the National or Ford's theatres, or picking up provisions at the Center Market. In addition to writing and publishing his poetry, Whitman contributed freelance journalism for New York and Washington newspapers, including the Star, one of the city's largest circulation dailies under the editorship of Crosby Stuart Noyes. Whitman's health during this time went from robust to precarious, partly as a result of his wartime ministry; in January 1873, he suffered a debilitating stroke which caused his removal to Camden, New Jersey, where he lived until his death in 1892.

The subject of Whitman's October 1872 newspaper piece and the source of his enormous laughter were political cartoons by Thomas Nast (1840-1902). They appeared in the October 26, 1872, edition of Harper's Weekly (available on the newsstands around October 16) during the closing weeks of the Presidential campaign between the Republican incumbent Ulysses S. Grant and the Liberal Republican/Democratic candidate Horace Greeley. The cover illustration was captioned, "None but the Brave Deserves the Fair." with the sub caption, "Miss Columbia May to H.G. December. 'Do you see any thing Green in my Eye?"' In it, Nast evokes the refrain from John Dryden's "Alexander's Feast; or, The Power of Music: An Ode in Honour of St. Cecilia's Day." But in place of Alexander wooing Thais following his victory in Persia, Nast depicts Horace Greeley attempting to woo Miss Columbia (an allegory of the U.S. Republic); she responds by asking if he thinks her credulous, while the true hero, Grant, approaches quietly on horseback to claim his deserved prize.

"That 'Tidal Wave' - 'We Are on the Home Stretch!'” appeared in a double-page spread. This is considered one of Nast's finer efforts, and it depicts Greeley and his fleet of prominent supporters (including Whitelaw Reid, who was serving as acting editor of Greeley's New York Tribune, Senators Charles Sumner and Carl Schurz, and Greeley's running mate Missouri Governor Benjamin Gratz Brown) being swamped by the electoral returns, while U.S. Grant sails peacefully into Washington harbor. The cartoon was printed several days following Republican victories in state and Congressional elections in Ohio, Pennsylvania, and Indiana, which were seen as an augury of Grant's victory in the November election. According to an analysis of this drawing in Harp- 
Week, the "Tidal Wave" was Nast's response to an earlier cartoon by his rival Matt Morgan in Frank Leslie's Illustrated Nerwspaper, which had depicted Senator Sumner as Moses commanding the Red Sea to close over the Pharaoh-like Grant. ${ }^{2}$ The remainder of the caption, "We are on the Home Stretch!," lampoons an optimistic October 9 editorial by Reid that predicted a Greeley victory despite the ominous recent election results.

Whitman salutes Nast as "the Moses who has smitten the rock" for figuratively leading the Pictorial Comic to the American promised land (Nast was Bavarian-born though raised in New York); the phrase also cleverly references Nast's riposte with Matt Morgan and indicates how intently Whitman had been following the election and its comic depictions. Whitman's paraphrase of Edward Bulwer-Lytton's maxim, "Beneath the rule of men entirely great, The pen is mightier than the sword," may be a nod to the homage reputedly paid to Nast by Grant, who credited his first election victory in 1868 to "the sword of Sheridan and the pencil of Thomas Nast." ${ }^{3}$

Whitman draws the "motley crowds, by dozens and scores, big and little, old and young, white, black and brown, learned and illiterate," with "a stray Senator or Representative, there a head of a bureau or even Department, swarms of clerks up to 9 o'clock, visitors, the colored people, the 'knights,' mechanics - the whole mass put in merry humor by these amusing cartoons." Such an inclusive enumeration is emblematic of the poetical Whitman, and the citizen-types are particular to the nation's capital. Whitman even included a topical reference to the presence of the Knights Templar, an order of Freemasonry that was hosting a delegation of visiting "Sir Knights" from Hartford, Connecticut, at the time the article appeared. ${ }^{4}$ Freemasons were well known to Whitman during this period, and the poet counted personal friends among their number, including his favorite photographer Alexander Gardner. ${ }^{5}$ Also at this time, Whitman entertained a certain romance with the Crusades (the Knights Templar emulated the medieval period) and made several (unsuccessful) attempts to frame the American Civil War in that light. ${ }^{6}$

The cartoons that Whitman applauds served to promote the election of Grant, and it is interesting to review the poet's view of this significant figure. Martin Buinicki observes Whitman's shifting assessment of Grant during the Washington years; the poet celebrated the general as the "noblest Roman of them all" at the Civil War's conclusion but expressed tepid support for Grant as a candidate and President. During the 1868 election, for example, Buinicki notes Whitman's presumed disagreement with Grant over Reconstruction (Grant was aligned with the Radical Republicans, whom Whitman distrusted), and the important issue of free trade (Whitman fervently supported it, whereas the Republican platform sought retention of the tariff). Indeed, rather than 
voting outright for Grant in 1868, Whitman paired off with a Democrat who would have canceled his vote, and both sat out the election. ${ }^{7}$ During Grant's first term, Whitman looked askance at some of the President's appointments, and observed from his own and his friends' perches in the Federal bureaus the many instances of malfeasance within the Grant administration.

Nevertheless, Whitman retained a personal admiration for Grant, and this piece of journalism broadcasts Whitman's support for the former General in the 1872 election. The enumeration of citizens in Whitman's Star report can be read as a subtle extension of Nast's overt partisan appeal on behalf of the Republican Presidential ticket. Whitman makes special reference to groups that the Republicans had courted that election season, including laborers and African Americans. An early campaign poster tried to reinforce the Republican standard-bearers as common workmen: harking back to their early vocational roots, Grant is depicted in a tanner's apron and jackboots, and his running mate Henry Wilson stands before his shoemaker's bench. The Republicans also worked assiduously to keep the newly-enfranchised African Americans in their camp, particularly after the abolitionist Senator Charles Sumner appealed to them to cast their votes for Greeley. ${ }^{8}$ Students of the District of Columbia's Howard University were even enlisted to campaign on Grant's behalf in the Southern states, which proved to be a successful strategy. Whitman also draws attention in his enumeration to Executive Branch employees (such as himself) beholden to the Republican President and his appointees for their positions in this age of patronage.

It is telling that Whitman enumerates African Americans twice (as "black" and "the colored people"), given Whitman's oft-noted ambiguity regarding the role of blacks in the American electorate. ${ }^{9}$ As recently as the summer of 1872, for instance, Whitman had allegedly argued "the unfitness of the negroes for voting," in the heat of an argument with his friend William Douglas O'Connor over Sumner's explicit appeal to blacks to vote for Greeley. ${ }^{10}$ It is also rather remarkable that Whitman includes "brown" people in his enumeration, which at this time and place would likely have been a reference to mixed race individuals. Popular fear of interracial unions had been used in earlier campaigns against the Republican Party, which was depicted as promoting miscegenation. ${ }^{11}$ Whitman's racial inclusiveness in the Star article, however, echoes sentiments expressed in his most recent public statement on the topic, contained in the preface to "As a Strong Bird on Pinion's Free" (1872). In it, Whitman prophesies that America's destiny is "to become the grand producing land of nobler men and women - of copious races, cheerful, healthy, tolerant, free-to become the most friendly nation, (the United States indeed) - the modern composite nation, form'd from 
all, with room for all, welcoming all immigrants . . . " 12

Looking back in 1874, Whitman wrote approvingly that Grant's re-election had safeguarded "the Reconstruction measures and the 13th, 14 th, and 15th Amendments . . . as organic and immutable elements of the Constitution ...."13 Despite the presence of Senator Sumner in their ranks, the Liberal Republican/Democratic alliance sought to end Reconstruction and re-enfranchise Southern whites who supported the rebellion, even at the expense of the newly enfranchised black man. No doubt Whitman's views were influenced by his work under Attorneys General Ebenezer Hoar, Amos T. Akerman, and George Henry Williams, whose newly formed Department of Justice (established in 1870) took the lead in implementing Grant's Southern Reconstruction policies. Akerman, for example, was instrumental in securing blacks' political rights by aggressively prosecuting the Klan under the provisions of the $\mathrm{Ku}$ Klux Klan Act of $1871 .{ }^{14}$

Whitman's attraction to these particular cartoons may also have been enhanced by the element of Comic Stoicism embodied in their portrayal of Grant, an element which George Hutchinson has identified as a defining characteristic of Whitman's own mid- to late-life personality. ${ }^{15}$ In the Nast pictures, we see the worthy Grant in the role of a mythic comic hero who remains steady to his own personality and principles while the hand of Fate or Nature overcomes seemingly intractable obstacles to deliver the hero his just rewards. In Grant's case, the obstacles were his erstwhile allies in the Union cause and the reward was the electorate's favor. Hutchinson notes that Whitman, beginning in the early 1870 s, began to employ Comic Stoicism as a psychological defense against the rejection of Leaves of Grass by the critical establishment; like a comic stoic hero, Whitman attempted to patiently suffer the critical abuse until Fortune shined on him the popular and critical acceptance he was owed.

Why did Whitman feel compelled to place himself as a character within this journalistic sketch? It was commonplace for Whitman to place himself within his own poems as a uniter of disparate urban types comprising his catalogues, and he seems to have the same objective here. Frances Dickey and M. JimmieKillingsworth have observed Whitman affecting such a role in order to translate rural community feeling into an urban setting.

The Whitmanian "myself" thus appears . . a as the overly familiar bumpkin, treating city strangers like old family friends, confronting urban aliens with the kind of insistent recognition formed in towns where everyone knows you, as Whitman would say, by your "nighest name." 16 
Such an affectation is particularly useful for creating an urban political coalition, which appears to be one of Whitman's aims in writing this piece of journalism.

Another aim is more mercenary. Whitman seeks to promote himself, much like our own day's celebrities who "tweet." As William Roscoe Thayer, the poet's friend, astutely observed,

We must remember that [Whitman] was a contemporary of P.T. Barnum and agreed with that master-showman's views of publicity; so he chose a style both in prose and verse which at once arrested attention; he did not blush to write for the newspapers puffs of himself and his works; he craved notoriety even of the flimsiest sort. "The public," he said to me, "is a thick-skinned beast, and you have to keep whacking away on its hide to let it know you're there."17

In 1872, Whitman was seeking an audience for the re-issued fifth (and what Whitman said at the time would be his final) edition of Leaves of Grass and a new pamphlet, "As a Strong Bird on Pinions Free, and Other Poems." 18 Depicting a mirthful self in the midst of a laughing assembly of fellow citizens may also have been an unconscious attempt by Whitman to show that he had been "as affectionately absorbed" by them as they had been by him. ("The proof of a poet is that his country absorbs him as affectionately as he has absorbed it," Whitman declaimed in the 1855 preface to Leaves of Grass. ${ }^{19}$

One interesting aspect of Whitman's presentation of his laughing self in the Star is the offhand but emphatic dismissal of "foreign critics" who think the poet incapable of mirth. Whitman may have directed this jibe specifically at a profile drawn of him by the American expatriate Moncure Conway, which had appeared several years earlier in London's Fortnightly Review. Conway described a visit he had made to Whitman in Brooklyn shortly after the publication of the first edition of Leaves of Grass (1855), and observed of Whitman:

I found him on the appointed morning setting in type in a Brooklyn printing-office, a paper from the Democratic Review, urging the superiority of Walt Whitman's poetry over that of Tennyson, which he meant to print (as he did everything, pro and con, in full) in the appendix of his next edition. He still had on the working-man's garb, which (he said) he had been brought up to wear, and now found it an advantage to continue. It became plain to me as I passed along the streets and on the ferry with him, that he was a prince incognito amongst his lower class acquaintances. They met him continually, grasped his hand with enthusiasm, and laughed and chatted (but on no occasion did he laugh, nor, indeed, did I ever see him smile). ${ }^{20}$

Conway's depiction of Whitman irritated the poet and his friends when it was first published in 1866, and continued to do so for years afterward. 
William O'Connor and John Burroughs chastised Conway privately; Colonel Richard Hinton did so publicly (in a March 7, 1868 newspaper piece), which Whitman noted approvingly to his mother: "my friend Col. Hinton (in his letter some weeks ago in the Rochester Express,) has given him, Conway, some pretty sharp cuts about his ridiculous anecdotes of me \& you too-Still Conway seems to mean all the good he can. But such descriptions of me as, 'he was never known to smile or laugh,' is altogether too jolly-don't you think so?" ${ }^{21}$ Whitman's abiding sensitivity to Conway's anecdote belies the indifference to criticism he sought to cultivate, and it seems to have blinded him to the fact that Conway's overall critical assessment of the poet was complimentary. Clearly Whitman had not fully integrated the stoicism he admired.

Several scholars have made the case for Whitman as a political humorist, which would also explain his attraction to Nast's comics, as well as his desire to dispel Conway's unsmiling caricature. Roger Asselineau notes that Whitman's prose work "The Eighteenth Presidency!" and his poems "A Boston Ballad" and "Respondez!" exemplify a type of political humor that uses "irony and bitter invective," 22 characteristics also found in Nast's political cartoons. Others have found a gentler humor in some of Whitman's poems, such as the one written in 1870 for the American Institute (later called "After All, Not to Create Only"), in which the muse of Democracy is found incongruously amidst "the kitchenware." It was important to Whitman that he be seen as possessing a funny bone, since "the spirit of fun" is a particularly American trait, as he observes in the closing paragraphs of the Star sketch, and Whitman always wanted to be seen as the representative American.

In the Star editorial, Whitman prophesies the development of the Pictorial Comic into a great American institution. From its roots in Renaissance Italy, caricature flowered under England's Hogarth in the eighteenth century and France's Daumier in the early nineteenth century, but America certainly came into its own in the mid-nineteenth century, with the success of Harper's Weekly (formed in 1857) and Vanity Fair (1859). By 1872, Thomas Nast was America's pre-eminent cartoonist, having risen with the Union cause that he raised up and the Tweed ring which he brought low. ${ }^{23}$ (Whitman shared Nast's passion for both causes.)

Whitman would have been particularly keen on the ability of editorial cartoonists to affect positive moral change through a medium accessible to the masses (even the illiterate can be educated through a well-drawn cartoon, as Tweed learned to his regret). In that respect, cartoonists satisfy Whitman's call in Democratic Vistas for "native authors, literatuses," who would participate in the refashioning of American civilization "with results inside and underneath the elections of Presidents or Congresses" by speaking to the "common people, the life-blood 
of democracy." ${ }^{24}$ These artists have a unique ability to address the ills of the body Politic, which Whitman in Democratic Vistas described as "saturated in corruption, bribery, falsehood, mal-administration." 25 Such cartoonists are particularly useful because of the dialogue they engage in with other cartoonists with opposing perspectives. Nast's parries with Morgan, for instance, led to such fruitful and educative exchanges. In such a way, the electorate has the opportunity to weigh the alternatives and make a better-informed political decision.

Nearly a century and a half later, Whitman's prescient prophesy of the development of Pictorial Comics is fulfilled in such successors to Nast as Matt Wuerker of Politico and Mike Keefe of The Denver Post, both of whom are recent recipients of the Pulitzer Prize for Editorial Cartooning. They are American institutions whose work makes us better citizens, surely, but, with Whitman, we love them for giving us some "good fun!"

\section{The Washington Friends of Walt Whitman}

\section{NOTES}

1 The transcription below is based on my review of the Yale manuscript. See also Edward Grier's transcription in Walt Whitman, Notebooks and Unpublished Prose Manuscripts, ed. Edward F. Grier (New York: New York University Press, 1984), 2: 905-907.

2 See: http://nastandgreeley.harpweek.com/subpages/cartoon-1872-MediumB. asp? UniqueID $=34 \&$ Year $=$ election.

3 Quoted in Albert Bigelow Paine, Th. Nast: His Period and His Pictures (New York: Macmillan, 1904), 129.

4 Washington Evening Star (October 16, 1872).

5 D. Mark Katz, Witness to an Era: The Life and Photographs of Alexander Gardner (New York: Viking Penguin, 1991), 264.

6 Martin T. Buinicki, Walt Whitman's Reconstruction (Iowa City: University of Iowa Press, 2012), 7-8, 152n14. Hereafter, $W W R$.

7 Ibid., 114-117.

8 Hon. Charles Sumner, "Letter to Colored Citizens, July 29, 1872" (Washington: F. \& J. Rivers \& Geo. A. Biley, 1872). Sumner's chief complaint against Grant was that the President had (unsuccessfully) attempted to annex Santo Domingo, a black Republic.

9 Ed Folsom provides numerous instances demonstrating how "wildly ambivalent" Whitman was "about the racial changes Reconstruction had brought about." See Folsom, "Lucifer and Ethiopia: Whitman, Race, and Poetics before the Civil War and After," in A Historical Guide to Walt Whitman, ed. David S. Reynolds (New York: Oxford University Press, 2000), 77.

10 Jerome Loving, Walt Whitman's Champion: William Douglas O'Connor (College Station, TX: Texas A\&M University Press, 1978), 96. 
11 An infamous example is the 1864 publication of a tract endorsing inter racial marriage, which claimed to reflect the official views of the Republican Party. The tract is now recognized as a hoax perpetrated by Democratic Party supporters. See David G. Croly, Miscegenation: The Theory of the Blending of the Races, Applied to the American White Man and Negro (New York: H. Dexter, Hamilton \& Co., 1864). Croly uses the term "brown" to describe the pure "Miscegen" product of a white and black union $(25,65)$. For additional discussion of this tract and Whitman's friendship with Croly, see Buinicki, WWR, 29, 32-35, 36-37, 155n49.

12 Walt Whitman, Complete Prose Works (Philadelphia: McKay, 1892), 277. Available on the Walt Whitman Archive (whitmanarchive.org). Hereafter, CPW.

13 Library of Congress, Feinberg-Whitman Collection (Reel No. 8). Whitman recorded this observation of the 1872 election in the margins of a newspaper clipping regarding Grant's nomination of Morrison Remick Waite to be Chief Justice of the United States. The newspaper clipping has a dateline of Washington, January 20 [1874]. The Thirteenth Amendment abolished slavery; the Fourteenth Amendment gave citizenship to former slaves; and the Fifteenth Amendment gave male former slaves the right to vote.

14 Lewis L. Gould, Grand Old Party: A History of the Republicans (New York: Random House, 2003), 64-65.

15 George B. Hutchinson, “The Laughing Philosopher: Whitman's Comic Repose,” Walt Whitman Quarterly Review 6 (Spring 1989), 172-188.

16 Frances Dickey and M. Jimmie Killingsworth, "Love of Comrades: The Urbanization of Community in Walt Whitman's Poetry and Pragmatist Philosophy," Walt Whitman Quarterly Review 21 (Summer 2003), 10.

17 William Roscoe Thayer, "Personal Recollections of Walt Whitman," in Whitman in His Own Time, ed. Joel Myerson (Detroit: Omnigraphics, 1991), 304. Originally published in Scribner's (June 1919).

18 Luke Mancuso, "Leaves of Grass, 1871-1872 Edition," in Walt Whitman: An Encyclopedia, ed. J.R. Le Master and Donald D. Kummings (New York: Garland Publishing, 1998), 368-371, hereafter, Walt Whitman: An Encyclopedia. Mancuso reads the fifth edition of Leaves of Grass as embodying "Whitman's egalitarian solidarity against the white majority, who were resisting the widening of liberties for marginalized minorities."

19 Whitman, Leaves of Grass (Brooklyn: 1855), xii. Available on the Walt Whitman Archive (whitmanarchive.org).

20 Moncure Conway, "Walt Whitman," Fortnightly Review 6:35 (October 15, 1866), 545.

21 Walt Whitman, The Correspondence, ed. Edwin Haviland Miller (New York: New York University Press, 1961), 2:30. Hinton's letter was published on March 7, 1868. Even late in life, Whitman hadn't fully forgiven Conway for this depiction. In a conversation with Horace Traubel, Whitman said, "I can't help feeling still a little suspicion of Conway's lack of historic veracity: he romances: he has romanced about me: William says lied: but romanced will do. I don't feel sore or ugly about it: it only makes me watchful." Horace Traubel, With Walt Whitman in Camden, 3:16; available on the Walt Whitman Archive (whitmanarchive.org).

22 Roger Asselineau, "Humor" in Walt Whitman: An Encyclopedia, 289-290. 
23 Edward Lucie-Smith, The Art of Caricature (Ithaca, NY: Cornell University Press, 1981), 51, 52, 77, 87, 88.

24 Whitman, $C P W, 206,225$.

25 Ibid., 210. 